\title{
Renal artery embolisation: indications and utilisation at Tygerberg Hospital
}

\author{
R Pretorius, ${ }^{1}$ S Vlok, ${ }^{2}$ A van der Merwe, ${ }^{1}$ AD Zarrabi, ${ }^{1}$ K du Toit ${ }^{3}$ \\ ${ }^{1}$ Department of Urology, Stellenbosch University and Tygerberg Hospital, Cape Town, South Africa \\ ${ }^{2}$ Department of Radiology, Stellenbosch University and Tygerberg Hospital, Cape Town, South Africa \\ ${ }^{3}$ Urologist in private practice, Cape Town, South Africa
}

Corresponding author: Dr Rupert Pretorius (rupertpretorius@gmail.com)

\begin{abstract}
Background: To evaluate the indications, efficacy and outcomes of endovascular renal artery embolisation (RAE) in the management of renal haemorrhage, specifically in cases of non-iatrogenic origin.

Methods: This is a retrospective case note review of 92 patients who underwent RAE in the period from August 1999 to August 2014 at Tygerberg Hospital.

Results: Renal artery embolisation was performed in a total of 92 patients. The indication was traumatic renal injury in 60 patients $(65.2 \%)$, with mean age 28.2 years. The mechanism of injury was stabbing $(55.4 \%)$, blunt trauma (7.6\%) and gunshot (2.2\%). Digital subtraction angiography (DSA) showed pseudo-aneurysm in $32.6 \%$, arteriovenous fistula in $19.6 \%$ and segmental artery injury in $13 \%$. Embolisation success: $85 \%$ after one, $88.9 \%$ after a second attempt, with an overall success rate of $98.3 \%$ after two attempts. In 20 of the 92 patients (mean age 50.2 years) the indication was malignancy $(21.7 \%)$. Other cases included iatrogenic haematuria (4.3\%) and angiomyolipoma (3.3\%). Embolisation was repeated in $16.3 \%$, with eventual success rate of $93.8 \%$. Post-embolisation syndrome was the most common complication, seen in $9.8 \%$ of all cases. Of the 9 patients who returned for follow-up with renogram imaging, 4 had a differential function of $>20 \%$ of the embolised kidney.

Conclusion: Renal artery embolisation remains a very successful method of managing renal haemorrhage at this hospital, whether this results from trauma, malignancy, iatrogenic or other causes.
\end{abstract}

Keywords: renal artery embolisation, pseudo-aneurysm, renal trauma, endovascular management

S Afr J Surg 2019;57(4)

http://dx.doi.org/10.17159/2078-5151/2019/v57n4a2819

\section{Introduction}

After the advent of renal artery embolisation (RAE) in the $1970 \mathrm{~s},{ }^{1,2,3}$ there have been numerous advances and experiences with the method. Indications have broadened from managing renal bleeds due to malignant or benign renal lesions to iatrogenic injury and traumatic renal bleeds. Other indications include pre-nephrectomy and pre-radiation infarction of renal tumours as well as for palliation of unresectable malignancies and/or vascular malformations. ${ }^{4}$ Preoperative RAE has the potential to decrease intraoperative blood loss, operative time and transfusion requirements. . $^{5-7}$

Due to ever-smaller diameter of endourological catheters and improved imaging techniques, super selective embolisation is possible, reducing the size of the post-embolisation renal infarct, contributing to nephron sparing. ${ }^{8,9}$ Infarction of less than $10 \%$ of nontarget renal parenchyme (not leading to significant functional reduction) has been reported. ${ }^{10}$

This study comprises the largest review of traumatic renal injuries managed with RAE in modern literature.

\section{Setting}

Tygerberg Hospital is a tertiary level training referral hospital in the Western Cape Province of South Africa, coupled to the University of Stellenbosch, Faculty of Medicine and Health Sciences. It also serves as a secondary level hospital to its immediate surrounding suburbs.

\section{Patients and methods}

This is a retrospective case note review of 92 patients who underwent RAE in the period from August 1999 to August 2014 at Tygerberg Hospital.

Ethical approval and waiver of informed consent was obtained from hospital management and the University of Stellenbosch. Patient information was gathered from Interventional Radiology (IR) theatre logbooks, the local electronic Enterprise Content Management (ECM) system, patient folders gathered from the hospital archives, as well as 
ward summaries and discharge notes compiled by doctors.

All patients who underwent RAE in the above period were included in the study, whether they were referred to IR by urologists, trauma surgeons or oncologists.

The primary imaging modality used to detect renal injuries in stable patients was Computerised Tomography-scans (CT), displaying arterial, portovenous and delayed phases.

A variety of Urological specialists and registrars managed the patients clinically, whilst a senior Radiology registrar, always under the supervision of an IR-Specialist, performed the renal artery embolisation procedure.

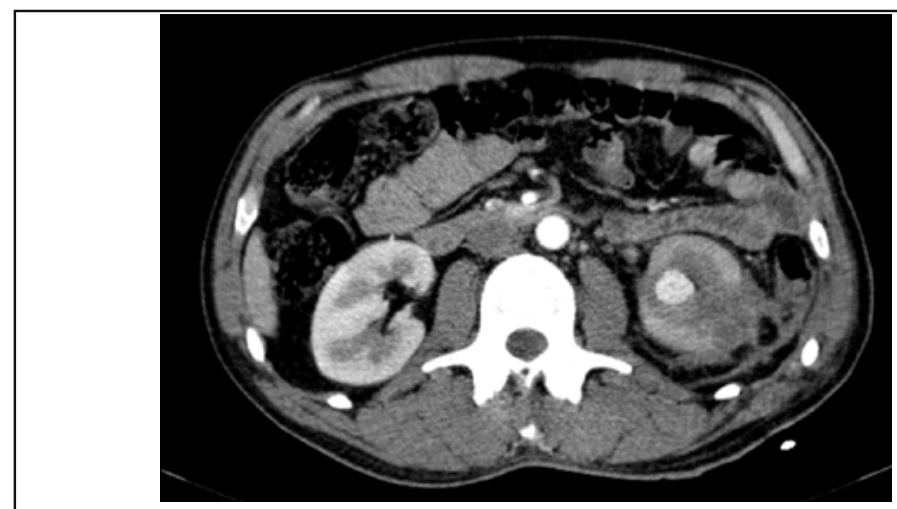

A

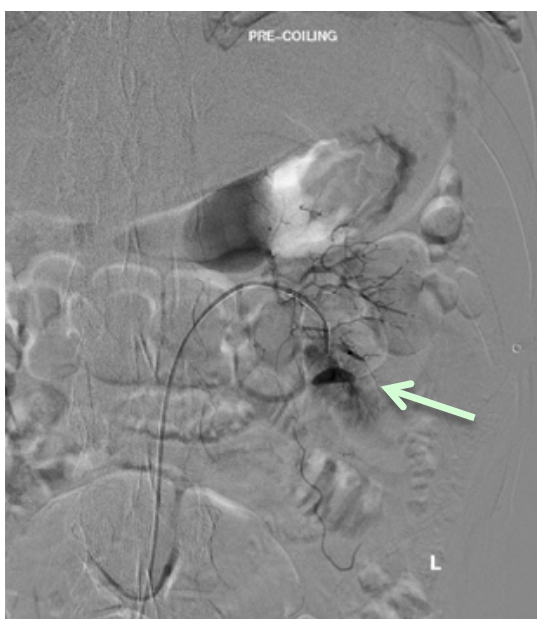

C

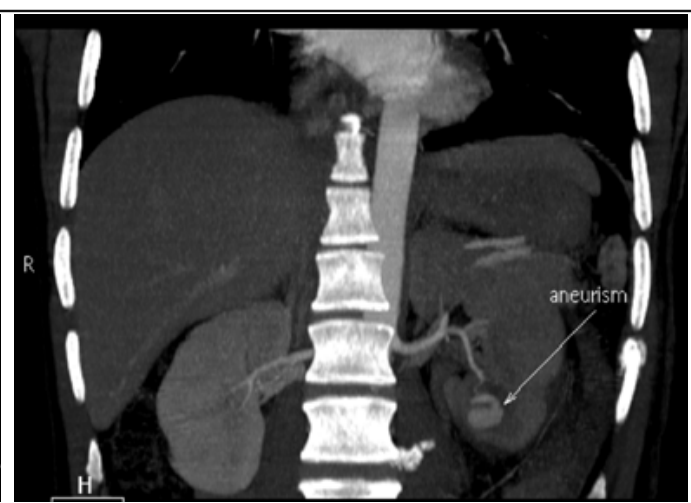

$B$

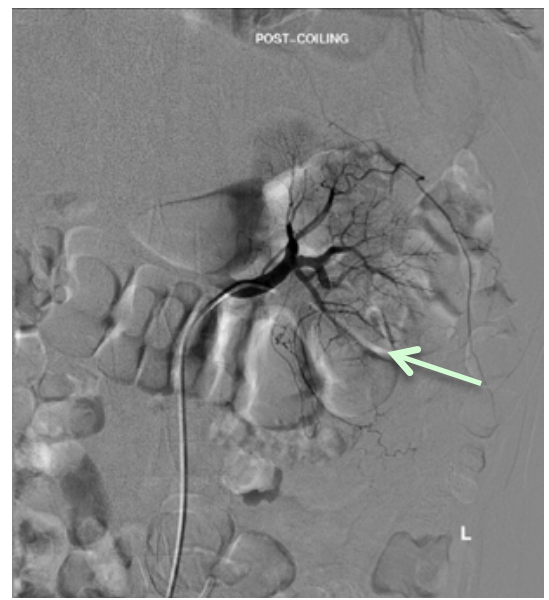

$D$

Figure 1. The lower segment of the anterior branch of the left renal artery was injured with a stab wound. A pseudo-aneurysm can be seen on the (A) axial-and (B) coronal views of the arterial phase of the CT IVP. (C-D) Sequential digital subtraction angiograms are seen. Pre-embolisation images delineate exact position. Successful employments of coils to occlude the bleeding vessel are shown, with resolution of the aneurysm and good collateral blood flow.

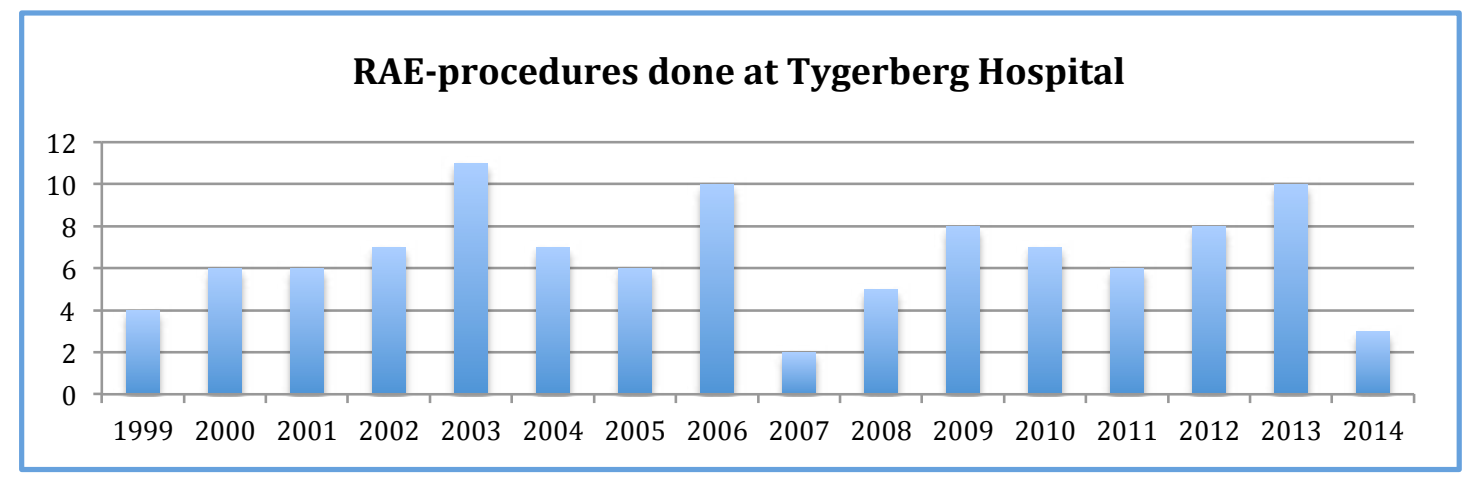

Figure 2. Number of RAE-procedures done at Tygerberg Hospital: August 1999 to August 2014. 
Table 1. Results of trauma cases

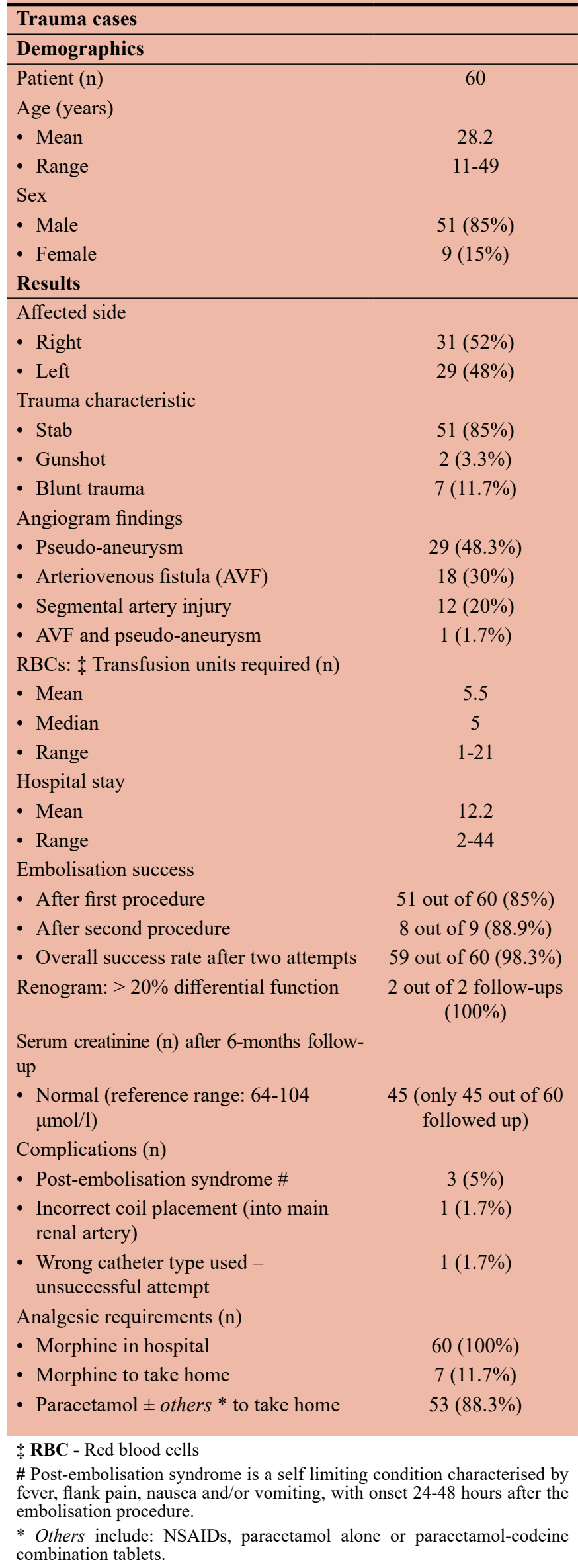

\section{Embolisation technique}

If no contra-indication existed, the common femoral artery (CFA) approach was used. Arterial access was gained with an 18 -gauge percutaneous entry needle, after which a 5 French sheath was placed and a 0.035 inch guide wire advanced. A 5 French catheter was advanced to the level of T11 and an aortagram and DSA (digital subtraction angiography) were performed and the site of bleeding identified. A 3 French or 5 French catheter was used to deploy the embolisation material. Non-absorbable titanium microcoils (product of Cook Medical ${ }^{\circledR}$, marketed as Marcus Medical ${ }^{\circledR}$, Midrand, South Africa) were used, with only a few cases done with alcohol. After each deployment of a coil, a subtraction digital imaging run was done, determining its position, related vascular flow and the need for further coiling. After total occlusion of the severed vessel, a confirmatory subtraction angiogram was done to demonstrate the avascular segment and patency of the remaining vessels. ${ }^{11,12}$ (See Figure 1.)

Post-procedure, a dedicated sister applied manual pressure to the groin puncture site for 10 minutes, as standard.

\section{Results}

A total of 92 patients underwent renal artery embolisation, with a total of 106 embolisation procedures performed. This population comprised of 60 traumatic (blunt and penetrating) renal bleeds and 32 cases of non-traumatic renal bleeds. (See Table 1 and 2.)

Figure 2 shows the number of RAE-procedures done at Tygerberg Hospital over time.

Of the 60 trauma patients, $51(85 \%)$ had presented with stab injuries, $2(3.3 \%)$ with gunshot wounds and 7 (11.7\%) with blunt trauma (including two falls from heights, four assault cases and one high velocity car accident). 51 (85\%) of the patients were male. Four $(6.7 \%)$ patients had undergone negative laparotomies by the trauma surgeons before they were referred for RAE.

Renal arteriography was generally done after a patient required transfusion with two or more (range: 1-21) units of packed red blood cells (RBCs).

One $(1.7 \%)$ initial diagnostic arteriogram did not show any obvious abnormality. On repeat arteriography a week later, for continual macroscopic haematuria requiring transfusion with a further 2 units RBCs, a bleeding segmental artery was seen and embolised.

The most common arteriographic finding was pseudoaneurysm (48.3\%), followed by arteriovenous fistula (30\%) and segmental artery injury $(20 \%)$.

In the trauma group, the success rate of RAE after one procedure was $85 \%$. Success was defined as cessation of haematuria and no further need for transfusion. After two attempts, success rate was $98.3 \%$. One case was not managed with repeat RAE, as the initial RAE-attempt failed and the patient became haemodynamically unstable. An open repair and ligation of the bleeding vessel was successfully done. 
Table 2. Results of non-trauma cases

\begin{tabular}{|c|c|}
\hline \multicolumn{2}{|l|}{ Non-trauma cases } \\
\hline \multicolumn{2}{|l|}{ Demographics } \\
\hline Patient (n) & 32 \\
\hline \multicolumn{2}{|l|}{ Age (years) } \\
\hline - Mean & 48.7 \\
\hline - Range & $19-70$ \\
\hline \multicolumn{2}{|l|}{ Sex } \\
\hline - Male & $17(53.1 \%)$ \\
\hline - Female & $15(46.9 \%)$ \\
\hline \multicolumn{2}{|l|}{ Results } \\
\hline \multicolumn{2}{|l|}{ Affected side } \\
\hline - Right & $17(53.1 \%)$ \\
\hline - Left & $15(46.9 \%)$ \\
\hline \multicolumn{2}{|l|}{ Condition characteristic } \\
\hline - Renal cell carcinoma & $19(59.4 \%)$ \\
\hline - Angiomyolipoma & $3(9.4 \%)$ \\
\hline - Renal urothelial carcinoma & $1(3.1 \%)$ \\
\hline - Renal artery aneurysm & $2(6.3 \%)$ \\
\hline - Cervix carcinoma with ureter obstruction & $1(3.1 \%)$ \\
\hline - Rectal carcinoma with ureter obstruction & $1(3.1 \%)$ \\
\hline - Continuous haematuria, unknown cause & $1(3.1 \%)$ \\
\hline - Iatrogenic & 4 (see below) $(12.5 \%)$ \\
\hline \multicolumn{2}{|l|}{ - PCNL } \\
\hline - Segmental artery injury & $1(3.1 \%)$ \\
\hline - Arteriovenous fistula & $1(3.1 \%)$ \\
\hline \multicolumn{2}{|l|}{ - Renal biopsy } \\
\hline - Arteriovenous fistula & $1(3.1 \%)$ \\
\hline \multicolumn{2}{|l|}{ - "Pigtail drain" insertion by IR } \\
\hline - Pseudo-aneurysm & $1(3.1 \%)$ \\
\hline \multicolumn{2}{|l|}{ 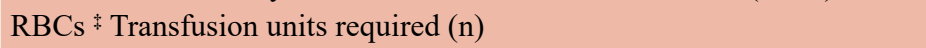 } \\
\hline - Mean & 4.5 \\
\hline - Median & 5 \\
\hline - Range & $1-12$ \\
\hline \multicolumn{2}{|l|}{ Hospital stay } \\
\hline - Mean & 19.5 \\
\hline - Range & $2-67$ \\
\hline \multicolumn{2}{|l|}{ Embolisation success } \\
\hline - After first procedure & 29 out of $32(90.6 \%)$ \\
\hline - After second procedure & 1 out of $3(33.3 \%)$ \\
\hline - After third procedure & 2 out of $2(100 \%)$ \\
\hline - Overall success rate after three attempts & 32 out of $32(100 \%)$ \\
\hline Renogram: $>20 \%$ differential function & $\begin{array}{l}2 \text { out of } 7 \text { follow-ups } \\
(28.6 \%)\end{array}$ \\
\hline \multicolumn{2}{|l|}{ Serum creatinine (n) after 6-months follow-up } \\
\hline - Normal (reference range: $64-104 \mu \mathrm{mol} / \mathrm{l})$ & $29(90.6 \%)$ \\
\hline - Increased & $3(9.4 \%)$ \\
\hline \multicolumn{2}{|l|}{ Complications (n) } \\
\hline - Post-embolisation syndrome \# & $6(18.8 \%)$ \\
\hline \multicolumn{2}{|l|}{ Analgesic requirements (n) } \\
\hline - Morphine in hospital & $28(87.5 \%)$ \\
\hline - Paracetamol \pm others $*$ in hospital & $4(12.5 \%)$ \\
\hline - Morphine to take home & $17(53.1 \%)$ \\
\hline - Paracetamol \pm others $*$ to take home & $15(46.9 \%)$ \\
\hline
\end{tabular}

$\$$ RBC - Red blood cells

\# Post-embolisation syndrome is a self limiting condition characterised by fever, flank pain, nausea and/or vomiting, with onset 24-48 hours after the embolisation procedure.

* Others include: NSAIDs, paracetamol alone or paracetamol-codeine combination tablets.
At 6-month follow-up, documented serum creatinine levels were within normal limits in 60 of the $60(100 \%)$ of patients. The two documented follow-up renogram scans showed differential function of $>20 \%$ of the embolised kidney: notably $34 \%$ and $24 \%$ function.

Of the 32 non-traumatic cases, the most common indication for RAE was renal cell carcinoma in 19 patients (59.4\%): 14 patients (43.7\%) underwent embolisation for metastatic renal cell carcinoma with haematuria requiring blood transfusion, 2 patients $(6.25 \%)$ had irresectable tumours with severe pain, 2 kidneys $(6.25 \%)$ were embolised preoperatively and 1 patient $(3.12 \%)$ had a demonstratable false aneurysm on CT-scan. The two mentioned follow-up renogram studies were for preoperative embolisation cases. Only four $(13.3 \%)$ cases were due to iatrogenic renal bleeds, two of these due to percutaneous nephrolithotomy (PCNL)-complications, one due to a renal biopsy and one due to a percutaneous pigtail drain inserted by IR for a perinephric collection.

The mean age of patients in the non-traumatic group was 48.7 years (range 19-70 years), compared to the 28.2 years in the trauma group (range $11-49$ years). The mean hospital stay in this group was 19.5 days (range 2-67 days), compared to 12.2 days (range 2-44 days) in the trauma group. $53.1 \%$ patients in this group were male.

Of the non-traumatic RAE-cases, the success rate of a single procedure was $90.6 \%$, with an overall success rate of $100 \%$ after 3 attempts.

Of the 32 patients $29(90.6 \%)$ showed a normal serum creatinine at 6-month follow-up. Of the other three patients, two were known with chronic renal failure prior to RAE and the last patient defaulted after her 6-month follow-up visit.

Of the 7 non-trauma patients who followed up with renogram studies, only $2(28.6 \%)$ had a differential function of $>20 \%$ of the embolised kidney (notably $30 \%$ and $37 \%$ ). Follow-up renograms were noted in 5 patients embolised for renal cancer, 1 patient embolised for iatrogenic renal injury post pigtail insertion and secondary haemorrhage and the last patient was embolised for a large idiopathic renal artery aneurysm. The 2 patients who showed followup differential renal function $>20 \%$ were in both cases embolised for bleeding renal cell carcinoma, showing that successful selective embolisation is possible in these cases.

Transfusion requirements of the trauma patients revealed a mean of 5.5 units RBCs (range: 1-21), with the non-trauma cases a mean of 4.5 units RBC's (range: 1-12). There was no statistically significant difference in RBC-requirements in patients receiving NSAIDs (nonsteroidal anti-inflammatory drugs) and those not.

Regarding analgesia, all patients received paracetamol as inpatients, with 26/92 (28.3\%) patients given a NSAID as additional analgesic. Trauma patients 
Table 3. Comparing the Tygerberg experience with the international community

\begin{tabular}{|c|c|c|c|}
\hline Series & RAE procedures & Success rates & Major complications \\
\hline Poulakis et al. ${ }^{4}$ & Total $n=5$ & $\begin{array}{l}\text { 1 RAE: } 80 \%(4 / 5) \\
\text { 2 RAE: } 100 \%(1 / 1)\end{array}$ & None \\
\hline Schwartz et al. ${ }^{5}$ & Total $n=121$ & $\begin{array}{l}\text { 1 RAE: } 98.3 \%(119 / 121) \\
\text { 2 RAE: } 100 \%(2 / 2)\end{array}$ & None \\
\hline Jain et al. ${ }^{13}$ & Total $n=41$ & $\begin{array}{l}1 \text { RAE: } 85.4 \%(35 / 41) \\
2 \text { RAE: } 100 \%(2 / 2)\end{array}$ & None \\
\hline Saour et al. ${ }^{15}$ & Total $n=10$ & 1 RAE: $100 \%(10 / 10)$ & $\begin{array}{l}\text { - Urinoma }(n=1) \\
\text { - Delayed nephrectomy }(n=1)\end{array}$ \\
\hline Wang et al. ${ }^{16}$ & Total $n=46$ & $\begin{array}{l}1 \text { RAE: } 89.1 \%(41 / 46) \\
2 \text { RAE: } 80 \%(4 / 5) \\
\geq 3 \text { RAE: } 100 \%(1 / 1)\end{array}$ & None \\
\hline Chiramel et al. ${ }^{17}$ & Total $n=66$ & $\begin{array}{c}\text { 1 RAE: } 71.7 \%(38 / 53) \\
\text { 2 RAE: } 54.5 \%(6 / 11) \\
\text { 3 RAE: } 100 \%(2 / 2)\end{array}$ & - Nephrectomy $(\mathrm{n}=3)$ \\
\hline Sam et al. ${ }^{18}$ & Total $n=50$ & $\begin{array}{l}1 \text { RAE: } 96 \%(48 / 50) \\
2 \text { RAE: } 100 \%(2 / 2)\end{array}$ & None \\
\hline Sommer et al. ${ }^{19}$ & Total $n=39$ & $\begin{array}{l}1 \text { RAE: } 94.9 \%(37 / 39) \\
2 \text { RAE: } 100 \%(4 / 4)\end{array}$ & $\begin{array}{l}\text { Accidental embolisation of upper renal pole }(n= \\
\text { 1) }\end{array}$ \\
\hline Corr and Hacking ${ }^{21}$ & Total $n=40$ & $\begin{array}{l}1 \text { RAE: } 87.5 \%(35 / 40) \\
\text { 2 RAE: } 80 \%(4 / 5)\end{array}$ & Partial nephrectomy $(\mathrm{n}=1)$ \\
\hline Wang et al..$^{23}$ & Total $n=83$ & 1 RAE: $96.4 \%(80 / 83)$ & Nephrectomy $(n=4)$ \\
\hline Tygerberg Hosital & Total $n=92$ & $\begin{array}{l}1 \text { RAE: } 87 \%(80 / 92) \\
\text { 2 RAE: } 75 \%(9 / 12) \\
\text { 3 RAE: } 100 \%(2 / 2)\end{array}$ & Accidental main renal artery embolisation $(n=1)$ \\
\hline
\end{tabular}

showed a higher in-hospital morphine requirement: $100 \%$ (all 60 patients) versus $87.5 \%$ (28 of 32 patients) of nontrauma patients. However, 53.1\% (17 patients) of non-trauma patients and only $11.7 \%$ ( 7 patients) of trauma cases required morphine as discharge analgesic.

The remainder of patients ( 68 of 92: 73.9\%) were discharged on paracetamol-codeine combination therapy, with a NSAID added in 29 of $68(42.6 \%)$ patients.

Post-embolisation syndrome, characterised by usually selflimiting fever, flank pain, nausea and/or vomiting, was present in $9.8 \%$ of patients.

In one patient, the non-absorbable coil was incorrectly placed in the main renal artery, with an inability to retrieve this coil endoscopically. Follow-up renogram after 6 months showed a differential function of $24 \%$ on the affected side, no hypertension, a normal serum creatinine level and an asymptomatic patient.

\section{Discussion}

The kidney is protected in its retroperitoneal position by adjacent vertebrae, musculature, perinephric fat, fascia layers (notably Gerota's fascia), surrounding organs and the peritoneum. A considerable force is required to injure this organ. It has a remarkable capacity to recover from even the worst of injuries. The kidney is, however, the most commonly injured organ in the urogenital tract. ${ }^{24}$
Acute renal haemorrhage is managed conservatively, as far as possible, to preserve renal function. The acronym "SNOM" (selective non-operative management), denoting a conservative management approach in trauma victims, has gained popularity over the past few decades; not only in liverand splenic injuries, but also in renal injuries. ${ }^{24-30}$

SNOM entails that the patient is admitted for bed rest and observed closely until the macroscopic haematuria clears and the haemoglobin level stabilises. Consistent or large bleeds requiring significant or repeated blood transfusions necessitate intervention. ${ }^{19-21,23,24}$

A variety of factors can cause renal haemorrhage. These include penetrating or blunt trauma, iatrogenic renal insults and malignant or benign renal lesions. ${ }^{5,8}$ When the degree of haemorrhage seems out of character to the injury, do not forget about possible medical conditions contributing to the haemorrhage.

Ever since its inception in the 1970s, RAE-procedures have grown in popularity and application. They are less invasive and with less morbidity than surgery and are thus an attractive alternative. The success rate from numerous case series and reviews report success rates between 85.3 and $98 \%$. (See Table 3.)

Haemodynamically unstable patients (due to renal haemorrhage) should be taken for an explorative laparotomy and possible nephrectomy. Most trauma patients can be resuscitated and stabilised well enough to undergo diagnostic imaging. ${ }^{24}$ A prior knowledge of the location and extent of the 


\begin{tabular}{ll} 
Table 4. Embolisation technique: A general classification \\
\hline $\begin{array}{l}\text { Embolisation } \\
\text { technique }\end{array}$ & Indication \\
\hline $\begin{array}{l}\text { Partial } \\
\text { embolisation }\end{array}$ & - Pseudo-aneurysm \\
& - Arteriovenous fistula / malformation \\
& - Segmental artery injury \\
& - Penal artery aneurysm \\
Total & Angiomyolipoma (bleeding or to reduce \\
embolisation & rupture risk) \\
& - Renal cell carcinoma palliation / \\
& haemorrhage \\
& - Pre-surgery or radiofrequency ablation \\
& Irreversible transplant rejection \\
& End-stage renal disease with severe nephrotic \\
& syndrome, hypertension of haematuria \\
& Polycystic kidney disease with intractable \\
& pain, severe hydronephrosis, persistent leak \\
& from ureterocutaneous fistula or severe \\
& hydronephrosis \\
- Prior to endograft placement for AAA-repair
\end{tabular}

injury allows for a faster embolisation procedure, reducing morbidity and theatre time. ${ }^{19}$ Our cases underwent CT IVPscans prior to embolisation.

Selecting the correct embolisation agent for the patient aids in achieving the desired result. Due to the significant trauma burden on our institution and the frequency of embolisation requests, our IR-department uses mostly titanium coils in cases of renal artery embolisation. Familiarity with and frequent use of coils have led to great success rates over a protracted period.

Side effects were minimal and none of previously published major complications, for example renal- or segmental artery dissection $^{20,21}$ or ureteric obstruction due to coil migration ${ }^{22}$ were observed.

After a failed first embolisation attempt (i.e., clinical failure due to continual haemorrhage), repeat arteriogram and/or repeat embolisation was done, with very high success rates (98-100\% in our series). Alternative follow-up investigations could include ultrasound with colour doppler (might show active bleed into a haematoma) or CT-angio to detect the cause of the continual bleed. ${ }^{17}$

Selective RAE will also infarct areas of healthy renal tissue. However, our review did not show a significant loss of global renal function (based on serum creatinine levels). Unfortunately, follow-up renogram studies were only done in selected cases, affecting selection bias. There is currently no set follow-up protocol for these patients in our setting. Poulakis et al. studied five patients who underwent RAE. Their follow-up mean differential renal function on DTPA nuclear renogram was $11.4 \%{ }^{4}$

More research regarding the effect of RAE on the differential function as given by a renogram may be of value, although most studies have shown that a more crude indicator of renal function, serum creatinine, is unaffected by RAE. ${ }^{8,10,15,18}$
Table 5. Available RAE-coil materials and proposed indications $\mathbf{s}^{5,8,16-19,21}$

\begin{tabular}{ll}
\hline Coil materials & - Metallic coils \\
& - Titanium / steel / platinum \\
& Particulate embolisation \\
& - PVA (polyvinyl alcohol) particles \\
& (permanent) \\
& - Gelfoam (biodegradable) \\
& - Liquid embolisation \\
& - Histoacryl / lipiodol glue \\
& - Gelatin \\
& - Absolute ethanol \\
Indication & - Large vessels \\
\hline Metallic coils & Lesion flow reduction \\
& Obliteration embolisation \\
Particulate or & End-artery embolisation (devascularising a \\
liquid & region) \\
Liquid & Sclerosis of vascular lesion / vascular bed
\end{tabular}

Other studies showed an infarcted area of $\leq 10 \%$, with no effect on renal function or blood pressure on follow-up. ${ }^{4,8,10,15,18}$

Embolising a part of the kidney will create an area of ischaemia, causing pain. Attention should be paid to adequate analgesic management. We found a large proportion of our patients (total 88 out of 92: 95.6\%) required in-hospital morphine. This complication, although the most common, is usually self-limiting.

Different types of embolisation materials are available. In this review, mostly titanium coils were used, whether for partial- or total embolisation. (See Table 4.)

There are many different coil materials available to be used. (See Table 5.)

The type of material used is based on the indication, physician preference, availability and cost. ${ }^{8}$

The relevance of RAE in modern medicine is worth our focus and study. It aids in relieving pressure on permanently overbooked emergency theatre slates, is less invasive and better tolerated than surgery.

\section{Study limitations}

This is a retrospective case note review of a single centre. This might introduce some bias. Tygerberg Hospital employs seasoned professionals and trainees, with some RAE procedures performed by specialists and others by senior registrars.

Mostly titanium coils are used as embolisation material at our institution and the results given above reflect success rates with this method.

\section{Conclusion}

Selective renal artery embolisation is an effective and safe means of managing acute renal bleeds at our hospital. The 
accompanying infarction of normal renal parenchyme has not been shown to have any clinically significant long-term deleterious effects. This study demonstrates its efficacy in trauma, avoiding the need for open surgical intervention in all but one case. Selective renal artery embolisation should be the first line management in patients presenting with renal trauma and severe haematuria.

\section{Conflict of interest}

None

\section{Orcid}

R Pretorius (iD http://orcid.org/0000-0002-0176-881

S Vlok (iD http://orcid.org/0000-0002-6579-971X

A van der Merwe (D) http://orcid.org/0000-0002-2006-8331

A Zarrabi (iD http://orcid.org/0000-0002-1504-6410

\section{REFERENCES:}

1. Kalish M, Greenbaum L, Silber S, Goldstein H. Traumatic renal hemorrhage treatment by arterial embolization. J Urol. 1974;112(1):138-41. Available from: http://dx.doi.org/10.1016/ S0022-5347(17)59662-7 PMID: 4835089

2. Turini D, Nicita G, Fiorelli C, Selli C, Villari N. Selective transcatheter arterial embolization of renal carcinoma: an original technique. J Urol. 1976;116:419-21. . Available from: http://dx.doi.org/10.1016/S0022-5347(17)58840-0 PMID: 1053325

3. Bookstein JJ, Ernst CB. Vasodilatory and vasoconstrictive pharmacoangiographic manipulation of renal collateral flow. Radiology. 1973;108:55. Available from: http://dx.doi. org/10.1148/108.1.55 PMID: 4709048

4. Poulakis V, Ferakis N, Becht E, Deliveliotis C, Duex M. Treatment of renal-vascular injury by transcatheter embolization: immediate and long-term effects on renal function. J Endourol. 2006;20(6):405-9. Available from: http:// dx.doi.org/10.1089/end.2006.20.405 PMID: 16808653

5. Schwartz MJ, Smith EB, Trost DW, Vaughn ED Jr. Renal artery embolization: clinical indications and experience from over 100 cases. Brit J Urol. 2006;99:881-6. Available from: http://dx.doi. org/10.1111/j.1464-410X.2006.06653.x PMID: 17166242

6. Bakal CW, Cynamon J, Lakritz PS, Sprayregen S. Value of Preoperative renal artery embolization in reducing blood transfusion requirements during nephrectomy for renal cell carcinoma. J Vasc Interv Radiol. 1993;4:727-31. Available from: $\quad$ http://dx.doi.org/10.1016/S1051-0443(93)71958-2 PMID: 8280991

7. Klimberg I, Hunter P, Hawkins IF, Drylie DM, Wajsman Z. Preoperative angioinfarction of localized renal cell carcinoma using absolute ethanol. J Urol. 1985;133:21-4. Available from: http://dx.doi.org/10.1016/S0022-5347(17)48768-4 PMID: 3964874

8. Ginat DT, Saad WEA, Turba UC. Transcatheter renal artery embolization: Clinical applications and techniques. Tech Vasc Intervent Rad. 2009;12(4):224-39. Available from: http://dx.doi. org/10.1053/j.tvir.2009.09.007 PMID: 20005480

9. Breyer BN, McAninch JW, Elliot SP, Master VA. Minimally invasive endovascular techniques to treat acute renal hemorrhage. J Urol. 2008;179(6):2248-53. Available from: http://dx.doi.org/10.1016/j.juro.2008.01.104 PMID: 18423679

10. Benson DA, Stockinger ZT, McSwain NE Jr. Embolization of an acute renal arteriovenous fistula following a stab wound: case report and review of the literature. Am J Surg. 2005;71:62-

\section{PMID: 15757060}

11. Davis C, Boyett T, Caridi J. Renal artery embolization: Application and success in patients with renal cell carcinoma and angiomyolipoma. Semin Intervent Rad. 2007;24(1):1116. Available from: http://dx.doi.org/10.1055/s-2007-971185 PMID: 21326748

12. Irwine CI, Kay D, Kirsch D, Milburn JM. Renal artery embolisation for the treatment of renal artery pseudoaneurysm following partial nephrectomy. Ochsner J. 2013 Summer;13(2):259-63. PMID: 23789014

13. Jain V, Ganpule A, Vyas J, et al. Management of non-neoplastic renal hemorrhage by transarterial embolization. Urology. 2009;74:522-6. Available from: http://dx.doi.org/10.1016/j. urology.2008.11.062 PMID: 19589577

14. Perini S, Gordon RL, LaBerge JM, Kerlan RK Jr, Wilson MW, Feng S, et al. Transcatheter embolization of biopsy-related vascular injury in the transplant kidney: Immediate and longterm outcome. J Vasc Interv Radiol. 1998;9:1011-9. Available from: $\quad$ http://dx.doi.org/10.1016/S1051-0443(98)70442-7 PMID: 9840051

15. Saour M, Charbit J, Millet I et al. Effect of renal angioembolisation on post-traumatic acute kidney injury after high-grade renal trauma: a comparative study of 52 consecutive cases. Injury, Int J Care Injured. 2014;45:894-901. Available from: http://dx.doi.org/10.1016/j.injury.2013.11.030PMID: 24456608

16. Wang C, Mao Q, Tan F, Shen B. Superselective renal artery embolization in the treatment of renal hemorrhage. Ir J Med Sci. 2014;183:59-63. Available from: http://dx.doi.org/10.1007/ s11845-013-0972-4 PMID: 23733504

17. Chiramel GK, Keshava SN, Moses V, Kekre N, Tamilarasi V, Devasia A. Clinical outcomes of endovascularly managed iatrogenic renal hemorrhages. Indian J Radiol Imaging. 2015;25(4):380-90. Available from: http://dx.doi. org/10.4103/0971-3026.169454 PMID: 26752819

18. Sam K, Gahide G, Soulez G, et al. Percutaneous embolization of iatrogenic arterial kidney injuries: Safety, efficacy, and impact on blood pressure and renal function. J Vasc Interv Rad. 2011;22(11):1563-8. Available from: http://dx.doi. org/10.1016/j.jvir.2011.06.020 PMID: 21840226

19. Sommer CM, Stampfl U, Bellemann N, et al. Patients with life-threatening arterial renal hemorrhage: CT angiography and catheter angiography with subsequent superselective embolization. Cardiovasc Inter Rad. 2010;33:498-508. Available from: http://dx.doi.org/10.1007/s00270-009-9787-0 PMID: 20049594

20. Mavili E, Dönmez H, Ozcan N, Sipahioğlu M, Demitraş A. Transarterial embolization for renal arterial bleeding. Diagn Interv Radiol. 2009;15(2):143-7. PMID: 19517386

21. Corr P, Hacking G. Embolization in traumatic intrarenal vascular injuries. Clin Radiol. 1991;43:211-6. Available from: http://dx.doi.org/10.1016/S0009-9260(05)80252-1 PMID: 2025999

22. Rajesparan K, Partridge W, Taha N, Samman R, Aldin Z. Early migration and ureteric obstruction of an embolisation coil used to treat massive haemorrhage following percutaneous nephrolithotomy. Cardiovasc Inter Rad. 2011;34:868-72. Available from: http://dx.doi.org/10.1007/s00270-011-0178-y PMID: 21638148

23. Wang HL, Xu CY, Wang HH, Xu Y. Emergency transcatheter arterial embolization for acute renal hemorrhage. Medicine (Baltimore). 2015;94(42):1-6. Available from: http://dx.doi. org/10.1097/MD.0000000000001667 PMID: 26496273 
24. Adams AC. Renal trauma: When to embolize? Curr Surg Rep. 2016;4(7):23. Available from: http://dx.doi.org/10.1007/ s40137-016-0144-3

25. Moolman C, Navsaria PH, Lazarus J, Pontin A, Nicol AJ. Nonoperative management of penetrating kidney injuries: A prospective audit. J Urol. 2012;188(1):169-73. Available from: http://dx.doi.org/10.1016/j.juro.2012.03.009 PMID: 22591960

26. Heyns CF, Van Vollenhoven P. Increasing role of angiography and segmental artery embolization in the management of renal stab wounds. J Urol. 1992;147(5):1231-4. Available from: https://dx.doi.org/10.1016/S0022-5347(17)37524-9 PMID: 1569655

27. Tsui A, Lazarus J, Van As AB. Non-operative management of renal trauma in very young children: experiences from a dedicated South African paediatric trauma unit. Injury, Int $\mathbf{J}$ Care Injured. 2012;43:1476-81. Available from: http://dx.doi. org/10.1016/j.injury.2010.12.027 PMID: 21269622

28. Clarke DL, Thomson SR, Madiba TE, Muckart DJ. Selective conservatism in Trauma Management: A South African Contribution. World J Surg. 2005;29(8):962-5. Available from: http://dx.doi.org/10.1007/s00268-005-0131-9 PMID: 15983718

29. Mantica G, Kruger S, Ackermann H, Spies PV, Cassim F, Keyser Z, et al. Retained bullet in the kidney: Imaging and conservative management. Urology. 2018;113:e3-e4. Available from: http://dx.doi.org/10.1016/j.urology.2017.11.044 PMID: 29225120

30. Squires Y, Laing GL, Bruce JL, Oosthuizen GV, Clarke DL. A case of selective non-operative management of penetrating gunshot wound injury of the liver and kidney in a pregnant patient. S Afr J Surg. 2015;53(3,4):67-9. PMID: 28240488 